\title{
VICTIMS OF CRIME AND HARMONIZATION OF THE LEGAL REGULATION OF THEIR RIGHTS IN THE EU AND THE CZECH REPUBLIC
}

\author{
Michal Malacka \\ Palacký University Olomouc, Czech Republic \\ michal.malacka@upol.cz
}

MALACKA, Michal. Victims of crime and harmonization of the legal regulation of their rights in the $\mathrm{EU}$ and the Czech Republic., International and Comparative Law Review, 2020, vol. 20, no. 2, pp. 129-158. DOI: 10.2478/iclr-2020-0021

\begin{abstract}
Summary: This study reflect the international sources of law and documents relating to the protection and support of crime victims from the global and European point of view following the global and European Union concept and the importance of the Directive 2012/29/EU of the European Parliament and of the European Council of 25 October 2012. Establishing minimum rules on the rights, support and protection of victims of crime. This study will also introduce the most important sources of law and international context related to the victims of crime as an existing category of victims in general. The EU member states are obliged to reflect the views and needs of victims, to respect human dignity and the right to privacy, enable the possibility to receive fair compensation from the perpetrator or other sources, and to provide victims with material, medical, psychological and social assistance from state and non-governmental organizations. Concerning the other documents, what is also essential for victims to access their rights and influenced national Victims of Crime Acts is especially the Council Directive 2004/80/EC of 29 April 2004, relating to compensation to crime victims and Directive 2012/29/EU of the European Parliament and of the Council of 25 October 2012 establishing minimum standards on the rights, support and protection of victims of crime to be mentioned.
\end{abstract}

Keywords: position, victims, crime, legal, political, European Union, legal source, fair treatment, victimization, international documents, UN guide, vulnerable, European convention, compensation, minimum standards, directive, mechanisms

\section{Introduction}

The position of victims of crime in the legal, social, and political sectors is dependent on the role of their state and its activities. The role of the state is of primary importance. The institutional and legislative background established by the state and also its supportive role in the regulation and protection of the rights will be subject in the following researched field. This study has been elaborated on in the frame of the project Rivi: Rights of Victims of Survived Bodily Harm and Improved Access to Clinical Forensic Examinations at the Ludwig 
Boltzmann Institute of Human Rights and Institute of the Ludwig Boltzmann Gesellschaft. This project is important because of the comparative art of the analytic work concentrated on the services to victims of crime and the level of their protection. ${ }^{1}$

Determining assistance to crime victims is conditional; therefore it varies state to state on the global platform. Some countries offer much wider services to victims compared to the others. That's why it is necessary to compare regional integration activities and global aspects of public international law and its sources. The most significant European Union point of view is regional integration activities. $^{2}$

Because all of the aspects mentioned above, it is important to analyze and introduce the international sources of law and documents relating to the protection and support of crime victims from the global and European point of view Following the global and European Union concept the importance of the Directive 2012/29/EU of the European Parliament and of the European Council of 25 October 2012, establishing minimum rules on the rights, support and protection of victims of crime will be not forgotten. Rather it is combined with other important legal sources from the diplomatic and public international platform. ${ }^{3}$ This study will also introduce the most important sources of law and international context related to the victims of crime as an existing category of victims in general. ${ }^{4}$

From the point of view of this platform, the practitioners and also the researchers have to focus on the document regulating the protection and support of crime victims, the Declaration of Fundamental Principles of Justice for Victims of Crime and Abuse of Power. ${ }^{5}$ This declaration is regularly mentioned as the first significant international document in the research field, the declaration was adopted by the UN General Assembly on 29 November 1985. The declaration contains concepts of the types of victims and a couple lack of rights to which victims are entitled to not Divided into four basic parts - access to justice and fair treatment, restitution, compensation for damages and provision of services

1 Se closer at the https://bim.lbg.ac.at/en/rivi

2 Compared to that question LETSCHERT, Rianne, VAN DIJK, Jan The New Faces of Victimhood: Globalization, Transnational Crimes and Victim Rights, Springer Science \& Business Media, 2011, pp. 5-10

3 Compared with the final report on the implementation of Directive 2012/29/EU establishing minimum standards on the rights, support and protection of victims of crime, DE CASADEVANTE ROMANI, Fernández available at https://www.europarl.europa.eu/ doceo/document/A-8-2018-0168_EN.html (2016/2328(INI))

4 DE CASADEVANTE ROMANI, Fernández, International Law of Victims, Max Planck Yearbook, Vol. 14, 2010, pp. 219-272,227

5 DE CASADEVANTE ROMANI, Fernández, International Law of Victims, Max Planck Yearbook, Vol. 14, 2010, p. 219-272 
for victims the declaration sets the sum of minimum standards for the treatment of crime victims and is one of the most important declarations in this field. ${ }^{6}$

The declaration relates exclusively to victims of crime and of abuses of State power. The declaration does not touch on violations of international humanitarian law. The later Declaration of the Protection of All Persons from Enforced Disappearance in 1992 does describe these violations. However, it indicates an obligation of States to provide remedies for criminal violations by their agents, officials and quasi-officials. The measures contained in the Declaration should contribute to improving victim's access to criminal justice, fair treatment during the court proceedings, fair and adequate compensation, compensation of damages and services providing assistance and support to victims of crime. Furthermore, the Declaration recommends that measures should be taken to prevent victimization related to the misuse of power. The declaration sets a certain standard for proposed legislation on the situation of victims of crime. As a consequence, the UN member states have to establish corresponding conditions providing the necessary information and assistance during criminal proceedings to the victims of crime. The member states are obliged to reflect the views and needs of victims, to respect human dignity and the right to privacy, enable the possibility to receive fair compensation from the perpetrator or other sources, and to provide victims with material, medical, psychological and social assistance from state and non-governmental organizations. ${ }^{7}$

Another important international document was introduced by the UN in 1999 as a guide for the development of programs providing social, psychological, emotional, financial and other assistance to victims in criminal proceedings was introduced with the title UN Handbook on justice for victims. ${ }^{8}$ The Handbook pays attention to the issue of victimization and appeals to those who provide assistance to victims to recognize the impact of victimization on victims and thus

6 WALLER, Irvin, Rights for Victims of Crime: Rebalancing Justice, Rowman \& Littlefield Publishers, 2010, ISBN 1442207078, 9781442207073, 232 p.6 compared with the texture, [online] available at https://www.ohchr.org/en/professionalinterest/pages/victimsofcrimeandabuseofpower.aspx

7 WALLER, Irvin, Rights for Victims of Crime: Rebalancing Justice, Rowman \& Littlefield Publishers, 2010, ISBN 1442207078, 9781442207073, 232 p.6 compared with the texture, [online] available at https://www.ohchr.org/en/professionalinterest/pages/victimsofcrimeandabuseofpower.aspx , compare with Shapland, Joanna, the Guide for Practitioners Regarding the Implementation of the Declaration of Basic Principles of Justice for Victims of Crime and Abuse of Power: Report : Item 7 of the Provisional Agenda [for The] Eighth United Nations Congress on the Prevention of Crime and the Treatment of Offenders, Havana ...UN, 1990

8 More about the handbook see the publication of the Handbook on Justice for victims, on the use and application of the declaration of basic principle of justice for victims of crime and abuse of power, UNODC, Center for international crime prevention, New York, 1999 available at http https://www.unodc.org/pdf/criminal_justice/UNODC_Handbook_on_ Justice_for_victims.pdf 
understand the need for assistance in the relevant way. ${ }^{9}$ In general, the intensity of victimization is different depending on the age or other factors of each victim. International documents governing the victims position in criminal proceedings therefore governs the need for special treatment of vulnerable victims. Victims with characteristics that could be exploited by the perpetrators should be also protected by the state as far as possible from secondary victimization. ${ }^{10}$

Coming to the European platform and to the results of the regional integration legislation activities, it is necessary to introduce another important document dealing with the issue of compensation to victims of crime. It is the European Convention on the Compensation of Violent Crimes from the year 1988. The European Convention established binding minimum standards for the regime of the compensation of victims of violent crime from state resources. ${ }^{11}$ In 2004, Council Directive 2004/80/EC on compensation to crime victims was adopted, which obliges all Member States to implement mechanisms for compensation to crime victims. ${ }^{12}$

\section{Victims of crime and the European regional integration platform}

Regional integration activity supported by the legislative procedures of the correspondent political entities are the reasons for some differences between the American continent and the European integration platform represented most by the European Union. Analyzing the American circumstances, the situation is different in the categories of victims envisaged by the existing regional legal sources. There is a lack of larger binding legal effects. The European Union institutional norms have on the other hand a clear binding legal effect. The study cannot forget also about the Council of Europe. Within the RIVI project, a connected study was elaborated in the frame of the project RIVI by the colleagues Sabine Mandl and Julia Planitzer, that's why the mention of sources of law will introduce the role of the Council of Europe only in short informative way. ${ }^{13}$

Before introducing the most important sources of law and important conventions of the European Union, the European regional framework generally shall be summarized. The Council of Europe started with an interesting group of international norms related to the problematical aspects of victims and their

9 Ibid p.104

10 Compare all the aspects important for the field of victimization and secondary victimization Ibid 4, 86, 97, 105

11 To the structure and importance of the convention and also the member states compare the information's available at the https://www.coe.int/en/web/conventions/full-list/-/conventions/treaty/116, DE CASADEVANTE ROMANI, Carlos Fernández, International Law of Victims, , Max Planck Yearbook, Vol. 14, 2010, p. 219-272

12 Compare with the situation established after the Council meeting in tempera on 15 and 16 October 1999

13 DE CASADEVANTE ROMANI, Carlos Fernández, International Law of Victims, Max Planck Yearbook, Vol. 14, 2010, p. 219-272,228 
rights. There is a sum of resolutions and recommendations, as the Resolution (77) 27 on the compensation of victims of crime..$^{14}$ This resolution is based upon the reasons of equity and social solidarity, forming the guiding principles for the harmonization of national provisions in this field. Working with the prompt compensation of victims of crime, the subsidiarity compensation by the state and others. Later come the recommendation R (83) 7 from the 23 June 1983 on participation of the public in crime policy because of the need for a crime policy reflecting the interests of a victim..$^{15}$ After these introduced recommendations the Council of Europe adopted the European convention on the compensation of victims of violent crimes adopted on 24 November $1983 .{ }^{16}$

This activity has been followed by documents dealing with the protection and support of victims of crime as Council of Europe Recommendation R (85) 11 on the standing of victims in criminal law and criminal proceedings, Council of Europe Recommendation R (87) 21 on assistance to crime victims and victimization prevention and the Council Framework Decision on the standing of the victim in criminal proceedings and also the recommendation (2006) 8 of the committee of ministers On assistance to crime victims, adopted on 13 June $2006 .^{17}$

Concerning the other documents, what is also essential for victims to access their rights and influenced national Victims of Crime Acts is especially the Council Directive 2004/80/EC of 29 April 2004, relating to compensation to crime victims and Directive 2012/29/EU of the European Parliament and of the Council of 25 October 2012 establishing minimum standards on the rights, support and protection of victims of crime to be mentioned. The Victims of Crime Acts in EU Member States are the instruments implementing these directives. ${ }^{18}$

\subsection{Directive 2012/29/EU of the European Parliament and of the Council of 25} October 2012

The purpose of Directive 2012/29/EU of the European Parliament and of the Council of 25 October 2012 is to ensure that crime victims will receive information, support and protection, and involvement in criminal proceedings. Member States are obliged to ensure that victims are recognized and as such treated with respect, individually, sensitively, professionalism and without discrimina-

14 The text is available [online] at https://rm.coe.int/16804f3e59

15 The text is available [online] at https://www.barobirlik.org.tr/dosyalar/duyurular/hsykkanunteklifi/recR(83)7e.pdf

16 This is the convention number 116, on 24 November 1983, which entered into force on the first first 1998.this convention has been ratified by more than half member states of the Council of Europe.

17 DE CASADEVANTE ROMANI, Carlos Fernández, International Law of Victims, Max Planck Yearbook, Vol. 14, 2010, p. 219-272,229

18 DE CASADEVANTE ROMANI, Carlos Fernández, International Law of Victims, Max Planck Yearbook,, Vol. 14, 2010, p. 219-272,230 
tion. A portion of the directive is dedicated to the individual rights of the victims and thanks to this, the Directive became an inspiration for the Acts on Victims of Crime in the Member States and they were mainly driven by efforts to implement this Directive.

The Directive requires Member States to bring into force the laws, regulations, and administrative provisions necessary to comply with the Directive. The specific form of the measures will be set down by national law. Not all states succeeded in bringing the Act on Victims of Crime into line with the Directive by implementation deadline set for 16th of November 2015.

The Directive initially defines who the victim of a crime is. It is either a natural person who has suffered physical, mental or emotional harm, material loss that was directly caused by the crime, a family member of a person whose death was directly caused by the crime and who has suffered harm as a result of the death of that person. ${ }^{19}$ Following the directive, victims have the right to be understood, access to comprehensible communications, and to relevant information from the respective authority. ${ }^{20}$

Member States must ensure that information is provided to victims in a simple and accessible form, taking into account the personal characteristics of victims, including any disability, as this may affect the ability to communicate with one another in a mutually understandable manner. ${ }^{21}$ The directive establishes a right for victims to receive information. This provision causes the criminal justice authorities to provide extensive information proactively ex officio, rather than the onus being on victims to seek out such information for criminal justice authorities. Victims must be granted an effective way of access to information. ${ }^{22}$ The term information is important for the rights of the victims. Information may be provided orally and in writing, creating systems where there is an obligation on police officers, prosecutors, and judges to inform victims of their rights. However, the individual needs and personal circumstances of victims must be considered when providing information in each particular case. The information has to be provided without unnecessary delay. ${ }^{23}$

19 Compare the article 2 of the directive and the fact, that the Directive does not define a legal person as victim, and compare this with the 'victim' definitions of the Council of Europe Recommendations (2006) 8 on Assistance to Crime victims and Draft UN Convention on Justice and Support for Victims of Crime and Abuse of Power

20 Compared this with article 3 and article 4 of the directive and also compare it with the Recital 21 of the directive. Article 3 applies not only to article 4 but also to article 5, six and seven of the directive.

21 Thanks to the article 3 the Directive seeks to ensure, that victims understand and can make themselves understood during criminal proceedings (linguistically or otherwise) and that authorities pro-actively assist victims to do so throughout criminal proceedings.

22 Compare this with the Recital 21 and 23 of the directive; focusing on the broader meaning of the term competent authority. This term has to be understood covering all competent authorities acting in the criminal proceedings depending on national law.

23 Article 4 of the directive into use of an important group of obligations for the member 
It should in principle mean that a victim is informed as soon as the victim meets a competent official and can reasonably absorb such information. ${ }^{24}$

The Directive provides the rights of victims when making criminal complaints. This includes new rights for victims when making a complaint. The directive requires the authorities to provide the victim with at least a written acknowledgment that a formal complaint has been made. Victims are entitled to make their complaint in a language that they understand. That means that they have the right to receive linguistic assistance from the authorities free of charge. Authorities should assess the risk of biased or incorrect interpretation by such a person before accepting assistance connected to the right of the complaint According to the Directive, Victims also have the right to request a translation of a written acknowledgement if they do not understand the language of the document. ${ }^{25}$

The victim must be informed, at his request, of the time and place of the trial, the nature of the charges against the offender, the final judgment and other matters. All victims must be notified of their right to receive information. ${ }^{26}$ Only victims with an exact role in the relevant criminal justice system will be notified of their rights. In addition, it must be ensured that the victim is informed of any offenders' escape or release from imprisonment or custody and the victim is informed about any measures taken to protect the offenders from the first contact with the competent authority and thereafter at any relevant stage of the proceedings. As a negative aspect, the directive does not introduce the right for victims to lodge an appeal against a decision on releasing the offender, nor the right to be heard in the release procedure before the competent authorities. ${ }^{27}$

states and fulfilling them can be possible only if there is in every member state enough practitioners, properly trained to act and handle and compliance with the directive and its article 25.

24 Case-law of the European Court of Human Rights in Strasbourg has in relation to Article 6 of the Convention of Human rights and Fundamental freedoms used various criteria without undue delay, reasonable time etc.

25 Following the article 5 of the directive, the complaint may be made either orally or in writing, by various means. Written acknowledgment that has been made by a formal complaint has to contain the basic elements of the criminal offence. Practice shows that some Member States do not provide a copy of the complaint itself, so a written confirmation or acknowledgement is therefore a minimum requirement and should not necessarily change practices in Member States in which a copy of the complaint itself is always given to the victim. The Article 5 does not explicitly address the individual assessment procedure, but the correspondent procedure should be taken in to reflection of Articles 7 and 22. If There's translation needed, the translation must be provided free of charge in any language the victim understands.

26 Giving victims reasoned decisions, is important to allow victims to access justice. Moreover, it is also a basic form of respect and recognition of the victim. In addition, the right of victims to review a decision not to prosecute in Article 11 would not be effective without proper knowledge of the facts leading to a contested decision.

27 Please compare the text of article 6 with the recitals $26,27,28,29,30,31,32$ and 33. It is a 
The victim has the right to interpretation and translation, and these services are provided free of charge to the victim at their request. Together with the Directive 2010/64/EU on the right to interpretation and translation in criminal proceedings is article 7 . This is an important an important source for the interpretation regime in criminal proceedings, containing necessary instruments of modern communication technology. The most important right brought by the directive is the right to translation of the essential information establishing a link to the right of access to the material of the case. ${ }^{28}$

The Directive defines the right of access to victim support services, member States must ensure that victims have free access to confidential support services, before, during, for a reasonable period after the criminal proceedings. The right to support is one of the core rights in the Directive and the purpose of it is to ensure that victims and their family members have access to confidential support services free of charge. States should take measures to create a free and confidential support service in addition to general support services.

Victims should then have access to such services on the basis of their specific needs and the seriousness of the harm suffered as a result of the crime. Victims may also require support during proceedings and for an appropriate period thereafter, depending on each victims' needs. Both victim general and specialist support may be provided by governmental or non-governmental organizations, on a professional or voluntary basis. ${ }^{29}$

Victim support service providers are obliged to provide general and specialist support services as a minimum requirement. Analyzing the targeted and integrated support for victims with specific needs requires some clarification. An integrated approach when providing victim support should take into account the relationship between victims, perpetrators, children and their wider social environment to avoid the risk of assessing their needs in isolation or without acknowledging their social reality. Providers of support services are obliged to provide shelters and other forms of safe and accessible alternative accommodation, legal advice, medical and psychological counselling, as well as running

standard art of the work with the directives, using not only the text but also the important recitals for fulfilling the blanks in the text of the directives.

28 Please note that there is an important line between article 5 and article 7 of the directive. Also compare all the stated information with the text in the Recitals 34, 35 and 36. For example recital 34 provides an important clarification. Interpretation should be made available, free of charge, during questioning of the victim and to enable to the victim to participate actively in court hearings.

29 Important for the exact understanding of the article 8 of the directive are the Recitals 37 , 40,62 and 63 . The victim support is provided mainly by non-governmental organizations (NGOs) working on a voluntary basis. Compare this with the report of the European Institute for Gender Equality, [online] Available at http://eige.europa.eu/sites/default/files/ Violence-against-Women-Victim-Support-Report.pdf 
hotlines and other essential services for victims and their families, including a proper system of forensic examination services and methods. ${ }^{30}$

The Directive also specifies the rights of participation in the criminal proceedings itself, namely the right to be heard, according to which Member States shall ensure that victims can be heard and provided evidence, as well as to define specific rules under which this will take place and lay down national regulations to ensure that national legislation provides an opportunity for victims of crime to be heard and provided evidence during criminal proceedings. ${ }^{31}$ Furthermore, there are also established rights for the situations that the criminal proceedings will be stopped, for example, the right to review decisions to stop criminal proceedings and others. Following the directive the Member States had been invited to develop procedure in the criminal procedure code whereby a victim will be entitled to ask for a review of a decision not to prosecute. ${ }^{32}$

The Directive's regulation on restorative justice services obliges the States to take measures to protect victims from secondary victimization, intimidation and retaliation, to ensure that victims have access to safe and qualified restorative justice services.

The Directive tries to ensure that where such services are provided, safeguards are in place to ensure the victim is not further victimized as a result of the criminal process. ${ }^{33}$ The victim also has the right to legal aid and national law must provide for the appropriate legal framework to ensure that victims can use this right and that victims are informed about how and under what conditions they can access legal aid at their first contact with the competent authorities. ${ }^{34}$ The right to reimbursement of expenses is also important, so the victims are not prevented from actively participating in criminal proceedings because of financial limitations, only necessary expenses should be reimbursed to the extent that the victim is obliged or requested by the competent authorities to be present and actively participate in criminal proceedings. ${ }^{35}$ The right to return property

30 Needs assessment tools have to be prepared and linked to the individual assessments, presented in article 22 of the Directive. Following the Recitals 38, 39 and 40 of the directive the correspondent system of forensic examination practice has to be provided.

31 Article 10 of the directive and the recitals 41 and 42 are ensuring an opportunity for all victims in the frame of criminal proceedings. The procedural rules are left to national law.

32 Article 11 of the directive is showing, that the directive it sells respects national procedural of autonomy in the relationship to subordination among authorities, but at least victims of serious crime have the right to a review of a decision not to prosecute. Compare the article 11 with the Recitals 43, 44 and 45.

33 The Article 12 does not oblige the Member States to introduce restorative justice services if they do not have such a mechanism in place in national law. The Member States are according CJEU not obliged to use mediation. To the relationship of the article 12 and to the aspects of restorative justice see also the recital 46.

34 Right under the article 13 means the legal aid under national law, it should at least cover legal advice and legal representation free of charge.

35 Recital 47 states that Member States should not be obliged to reimburse legal fees which 
and the clarification within what timeframe and in what condition the property should be returned is specified in national criminal law legislation. The return of property should be free of charge for the victim. All costs related to returning the property should be borne by the State. ${ }^{36}$ The right to a decision on compensation from the offender in the course of criminal proceedings entitles a victim to obtain a decision on compensation by the offender within a reasonable time in the course of criminal proceedings, except where national law provides for such a decision to be made in other legal proceedings. ${ }^{37}$ The Directive regulates the rights of victims resident in another Member State. Member States must ensure that the victim can lodge a complaint in their State of residence if the victim was not able to do so in the State where the crime was committed or if the victim does not wish to do so in case of serious offences. The competent authorities have to take measures to alleviate the difficulties which victims may experience due to their residence in another Member State than the one where the crime was committed. ${ }^{38}$ The Directive also addresses the right to the protection of victims and the recognition of victims in need of special protection, according to which the victim must have measures to protect themselves and their family from secondary victimization. Protection from repeat victimization applies to all victims, but may be of particular importance in situations of gender-based violence and violence in close relationships, such as physical violence, harassment, sexual aggression, stalking, intimidation, or other forms of indirect coercion and measures against the risk of emotional or psychological harm and precautions for protecting their dignity during interrogation. Protection of the victim's dignity entails adopting measures guiding the behavior of professionals in contact with victims and ensuring that victims are treated in a sensitive and professional manner in accordance with their needs. ${ }^{39}$

Member States must also guarantee to crime victims the right to avoid contact between the victim and the perpetrator at the premises of the criminal proceedings ${ }^{40}$ The victim's right to protection in criminal investigations specifically

should be covered by legal aid). In practice, the Article focuses on travel expenses and loss of earnings.

36 Victims can ask to have their property returned sooner under certain circumstances, compare the Article 15 with the recital 48.

37 The Article 16 only deals with compensation from the offender, and not from the State. The practice in Member States varies significantly and options to ensure effective implementation are multiple. Important are also the information in recital 49.

38 Bilateral cooperation agreements, memoranda of understanding between within the Member States to ensure that networks are established and made available as and when required in cross-border cases, cross-border cooperation agreements are welcome. Please note also the importance of the recital 51.

39 The matter of domestic protection measures is not dealt with by the Directive. Article 5 of the Directive 2011/99/EU on the European Protection Order and Article 3 of the Regulation 606/2013/EU on the mutual recognition of protection measures in civil matters could be used as guidance here, together with the recitals 7 and 52 .

40 Unless the criminal proceedings require such kind of contact. This should be interpret- 
means that the interrogations should be conducted without undue delay after the complaint has been lodged, the number of interrogations should be kept to a minimum, and the victim should be able to be accompanied by a prosecutor or other person which the victim chooses. The purpose of this Article is primarily to prevent secondary victimization of all victims, not just vulnerable victims. ${ }^{41}$ The victim also has the right to privacy. Victims are in practice often treated without respect by media outlets and the public, leaving the victim with no rights to privacy, dignity or basic respect when involved in criminal proceedings. They are thus victimized a second time. As a solution, Member States should encourage the media and other subjects to take self-regulatory measures on ethical conduct towards victims. ${ }^{42}$

The Directive emphasizes the individual assessment of victims in order to identify the possible need for their special protection and thus Member States must ensure that victims are assessed individually. The personal characteristics of the victim, such as age, gender, ethnicity, social origin, sexual orientation, etc. must be especially taken into account. Additionally, the type and nature of the offense and the circumstances of the offense also play a significant role and must be therefore carefully considered. In the individual assessment, attention should also be given in particular to victims who have suffered considerable harm as a result of the severity of the crime, victims of hate crime or motivated discrimination, and victims whose relationship with or dependence on the offender makes them particularly vulnerable. In particular, victims of terrorism, organized crime, trafficking with human beings, gender-based violence, close-range violence, sexual violence, sexual abuse, hate crime, and disability victims are taken into account. ${ }^{43}$

The right to protection of victims with special protection needs during criminal proceedings includes the following measures. The victim testifies in premises equipped for victims with need of special protection and from experts trained to work with these victims or eventually from the person of same sex. All statements made by victims of sexual violence, gender-based violence or violence in a close relationship shall be made before a person of the same sex as the victim,

ed proportionately. Exceptions should be construed carefully at national level, to ensure transparency and avoid decisions on an arbitrary basis.

41 The member states could use during the implementation supporting professional codes of conduct for the criminal justice authorities in contact with victims of crime, and ensure that they have the protection of victims of crime as apriority in their work system.

42 Member States should explore how and if professionals in close contact with the victim, the crime scene or the case file could be guided in their potential contacts with the media. Member States' judicial authorities should have powers to restrict recording and reports on activities in the court room to protect victims' privacy. Compare this with the recital 54.

43 Following the Recital 56, a number of different aspects have to be taken into account during the assessment process. The purpose of individual assessment is to determine whether a victim is particularly vulnerable to secondary and repeat victimization, to intimidation and to retaliation during criminal proceedings. 
if the victim so wishes, except for when the victims testify before a prosecutor or a judge. During the trial, victims in need of special protection may use measures to prevent contact with the offender, measures to allow the victim to be questioned from the courtroom by means of communication technologies without being present in the court, measures to prevent questioning about the victim's private life, if there is no crime-related context, and precautions allowing the hearing without public participation. ${ }^{44}$

Furthermore, the Directive explicitly deals with the rights of child victims who are classified as victims in need of special protection. Except in the case where measures which may benefit victims in need of special protection in gen$\mathrm{eral}^{45}$, the statements made by child victims are audio-visually recorded and are used as evidence during criminal proceedings. If the age of the child is uncertain and there is a reason to believe that the victim is a child, the victim is presumed to be a child. ${ }^{46}$

In addition, the States should also take measures to raise awareness of the rights provided by this Directive. Doing so will reduce the risk of victimization, minimizes the negative effects of crime, and reduces the risk of secondary victimization, intimidation, and retaliation. These efforts should focus primarily on vulnerable groups such as children, victims of gender-based violence, and of violence in close relationships. These measures may include information campaigns or research and education programs, where appropriate also in cooperation with civil society organizations. ${ }^{47}$

44 During the implementation of the directive it was important for the member states to establish in national criminal codes practices to introduce the directive's listed protection measures as part of standard practice and working routines of criminal justice professionals.

45 Closer to that please see recital 60. Measures to protect child victims shall be adopted in their best interests, taking into account an assessment of their needs. The specific measures listed in Article 24 apply to child victims, in line with the child-sensitive character of this Directive. For this field of victims protection are also the Directive 2011/36/EU [online]. Available at http://eurlex.europa.eu/LexUriServ/LexUriServ.do?uri=OJ:L:2011:101:0001 :0011:EN:PDF; and Directive 2011/92/EU [online]. Available at http://eurlex.europa.eu/ LexUriServ/LexUriServ.do?uri=OJ:L:2011:335:0001:0014:EN:PDF important.

46 The member states of the European Union had two ensure that professionals working with child victims receive specialized training in how to communicate with young victims of crime and how to identify and limit the risk of revictimization. This is in a close relationship with the neediness for emphasizes of the correspondent training mentioned in Article 25 and 26 and the Recital 61, 62 and 63 of the Directive. Member States are obliged to ensure that officials, police officers and judicial staff are trained, so they are aware of the needs of victims and to be able to deal with victims impartially, with respect and professionally. The directive also requires establishment of national contact points. At national level, the emphasis will be put on inter-agency coordination among national authorities and agencies.

47 Please compare this with the texture of the recital 62 and 63. 


\section{Specific rights of the victims of crime in the legal system of the Czech Republic, Austria and Germany}

Referring to the victims of crime rights and the situation in Czech Republic we have to mention the term victim and its codification in the legal system of the Czech Republic. Precisely the term victim was codified in the act number 209/1997 Coll. with the title On providing financial assistance to victims of crime. Following this law and the legal text of paragraph number two and paragraph number three, a victim is a natural person, this person has been injured by a crime or this person should have been injured in this way. ${ }^{48}$ Following this law, every person feeling like a victim of a crime, he or she has to be also considered as a victim unless it is clear and evident that the opposite is true. Following the text of the law on victims of crime, we have to notice that the criminal procedure code does not use the term victim. This is a little paradox, because the procedure code is using in its terminology the term injured person. Injured person is a person injured because of the crime and also the person at whose expense the offender has enriched himself. ${ }^{49}$

A specific regime is given by the situations where the victim was killed during the action of the crime. In such a situation of a victim dying we can also consider as a victim the direct family relatives, adoptive parents, spouse or registered partners, sibling, also companions or persons providing or obliged to provide maintenance at the date of the death of the primary victim. ${ }^{50}$

Thanks to the new codification in the Act on victims of crime the position of a child and elderly person who are physically, psychologically handicapped, has changed also thanks to the modification of the definition of the vulnerable victim. Persons with sensory impairment or other persons in a situation or in circumstances that may be implemented by the case are now in a better protected position. Thanks to $₫ 2$ of the Law on victims of crime we can define new kinds of victims and the special acts of criminal acting codified in the criminal code. Such as the victims of violence and offense committed due to national, crimes caused by organized criminal groups involving also secondary harm, and reflecting criminal acts and victims because of the age, race, nationality or sexual orientation. ${ }^{51}$

48 Compare that with DURDÍK, Tomáš, ČÍRTKOVÁ, Ludmila, VITOUŠOVÁ, Petra, HÁKOVÁ, Daniela. Zákon o obětech trestných činů (č. 45/2013 Sb.). Komentář, Praha: Wolters Kluwer 2018, P. 456, pp. 4-10, ISBN978-80-7598-109-7 also $13 . \quad$ JELÍNEK, Jiří, GǨIVNA, Tomáš. Poškozený a obět trestného činu z trestněprávního a kriminologického pohledu. Praha Leges, 2012, p. 25.

49 See also in JELÍNEK, Jiří a kolektiv: Zákon o obětech trestných činu․ Komentář s judikaturou. 2. vydání. Praha: Leges, 2014, p. 16.

50 For details see $\$ 2$ paragraph 3 of Act No. 45/2013 Coll., On Victims of Crime and also DURDÍK, Tomáš, Č́́RTKOVÁ, Ludmila, VITOUŠOVÁ, Petra, HÁKOVÁ, Daniela. Zákon o obětech trestných činů (č. 45/2013 Sb.). Komentár̆, Praha: Wolters Kluwer 2018, comm. to $\$ 2$

$51 \S 2$ par. 4 Act No. $45 / 2013$ Coll., on Victims of Crime and the $\$ 168$ of the Criminal 


\subsection{Right to information}

The right to information is granted not only in the situation where the Police of the Czech Republic are involved. The special authorities securing the enforcement of law and assisting victims of crime are obliged to secure the right to information for the victims. The form and extent of the information is concentrated not only on the rights of the victims. The Czech legal system gives is the right to the exact and specific information handled in the act On crime victims, in the $\$ 7$ to $\$ 13$. With respect to the act No. $45 / 2013$ Coll., the information to the victims has to contain a general description about the rights and also the system and most probable development of the following criminal procedure. The information has to describe the position of the victim and also the possible position changing the status to the witness. ${ }^{52}$

The police are obliged to provide the information already in the first meeting with the victim. The victim shall not be in the position asking for the information. The information shall contain the specification of the professional bodies capable to serve with professional assistance, the information about criminal submissions, and also specifications of the possible financial aid or assistance. ${ }^{53}$

The police and other bodies, if they are active in the procedure, must secure information not only orally for the victim. Written material has to be handed over to the victim and the oral form is used for more detailed explanation. ${ }^{54}$

The explanation and also the extent of the information have to be appropriate for the position of the victims, especially if the victims have specific needs. The case summary and the decision what information is necessary or unnecessary in the exact situation has to be prepared with relevance to the exact case as well as the mental state of the victim because of the crime, whether the victim can or cannot understand all of the information all the information. ${ }^{55}$

As it was also mentioned above, not only the police are obliged to provide a case summary. Other authorities and competent institutions have to ask the vic-

Code, also $\$ 311$ of the Criminal Code and DURDÍK, Tomáš, ČÍRTKOVÁ, Ludmila, VITOUŠOVÁ, Petra, HÁKOVÁ, Daniela. Zákon o obětech trestných činů (č. 45/2013 Sb.). Komentár̆, Praha: Wolters Kluwer 2018, pp. 4-25

52 For the commentary of the Act see DURDÍK, Tomáš, ČÍRTKOVÁ, Ludmila, VITOUŠOVÁ, Petra, HÁKOVÁ, Daniela. Zákon o obětech trestných činů (č. 45/2013 Sb.). Komentářr, Praha: Wolters Kluwer 2018, pp. 55-57 see also JELÍNEK, Jiří a kolektiv.: Zákon o obětech trestných činů. Komentár s judikaturou. 2. vydání. Praha Leges, 2014, p. 55.

53 For details see Section 8 of Act No. 45/2013 Coll., on Victims of Crime and also GŘIVNA, Tomáš, ŠÁMAL, Pavel, VÁLKOVÁ, Helena. a kol., Zákon o obětech trestných činů. Komentár. 1. vydání. Praha : C. H. Beck, 2014, pp. 66 and following.

54 Compare that with 10. GřIVNA, Tomáš, ŠÁMAL, Pavel, VÁLKOVÁ, Helena. a kol., Zákon o obětech trestných činů. Komentár. 1. vydání. Praha : C. H. Beck, 2014, pp. 56-65.

55 DURDÍK, Tomáš, ČÍRTKOVÁ, Ludmila, VITOUŠOVÁ, Petra, HÁKOVÁ, Daniela. Zákon o obětech trestných činů (č. 45/2013 Sb.). Komentár̆, Praha: Wolters Kluwer 2018, P. 456, p. 55 and following 
tims. The victims are free to decide if they would like to receive specific information about the type and stadia of criminal proceedings, or the conditions of the termination of the criminal proceedings. Also the medical facilities or the institution of security detention have to inform the victim at the request of the victim about the release of the offender or about the interruption of the imprisonment or about all changes of the character or form of the treatment. There can be situations, where the victim is a foreigner and cannot speak Czech. In such a situation the entitled authority has to ensure that the victim will receive all necessary information in a language which the victim understands. The information can be also presented in an official language following the citizenship of the victim. Linguistic skills are not the only important conditions what have to be granted. Also the age of the victim, health of the victim and the mental state have to be reflected because of the comprehensible way and art of the information. ${ }^{56}$

In the situation where the victim does not request information or is not willing to hear or receive the information in a written form, the authority or the police have to inform the victim of a crime if they are sure that there is a reasonable concern that the victim is in danger. The authority, in most of the cases the police, is entitled to inform the victim about all important measures for ensuring the safety of the victim and also to inform the victim about all necessary information. ${ }^{57}$

\subsection{Right to professional assistance}

Right to professional assistance is oriented to victims. That's why an existence of the victim and the correspondent timeline and the criminal content the conditions for the professional assistance are. Speaking about expert assistance, this assistance includes psychological counseling, social counseling, legal aid and legal information and restorative programs. ${ }^{58}$ Reflecting on the above information, the victims are entitled to receive professional assistance for a victim, even if he or she is subjectively stipulating, they feel like victims. Simply, the victim can ask for professional assistance before, during, and after criminal proceedings have been started. Coming back to the sorts of expert assistance described above, we can start with legal aid and legal information.

56 GŘIVNA, Tomáš, ŠÁMAL, Pavel, VÁLKOVÁ, Helena. a kol., Zákon o obětech trestných činů. Komentár., 1. vydání. Praha : C. H. Beck, 2014, pp. 101-102 and also JELÍNEK, Jiří a kolektiv: Zákon o obětech trestných činů. Komentár s judikaturou. 2. vydání. Praha: Leges, 2014, p. 59.

57 DURDÍK, Tomáš, ČíRTKOVÁ, Ludmila, VITOUŠOVÁ, Petra, HÁKOVÁ, Daniela., Zákon o obětech trestných činů (č. 45/2013 Sb.). Komentář, Praha: Wolters Kluwer 2018, p. 59

58 For the exact acts see GŘIVNA, Tomáš, ŠÁMAL, Pavel, VÁLKOVÁ, Helena. a kol., Zákon o obětech trestných činů. Komentár. 1. vydání. Praha : C. H. Beck, 2014, pp. 45-49 also Durdík,T., Č́rtková, L., Vitoušová, P., Háková, D., Zákon o obětech trestných činů (č. 45/2013 Sb.). Komentář, Praha: Wolters Kluwer 2018, P. 456, p. 52 
Speaking about expert and professional help in the process of legal representation of the victim and all possible forms of court proceedings, first we have to analyze the advocacy in Czech Republic and the corresponding legal regulation in this sector. The Law on advocacy describes legal aid as representation in proceedings before courts and other authorities, defense in criminal matters, legal advice, drafting of documents, processing of legal analysis, and other forms of legal assistance if they are performed systematically and for remuneration. ${ }^{59}$

Legal aid differs from psychological and social assistance and services. Social assistance may be provided to victims by entities authorized to provide social counseling and social prevention services. This sector is regulated by the law and provisions of social services and is also important for the assistance of the state and the possibility for the subsidy from the state budget. Mentioned above, the legal information may be provided by accredited subjects and we have to differ between legal aid and social services. ${ }^{60}$ The Czech legal system distinguishes the legal aid that can be offered only by lawyers even if there is a possibility to pay the lawyer or use the system where the victim is using legal aid provided free of charge if the situation is fulfilling conditions described in the Criminal code. ${ }^{61}$

Connected to the problems described in this part of the study it is important also to mention what is the role of the Ministry of Justice in the functional or nonfunctional conditions of the described system, presented and prepared by the law On Crime Victims. Following the $\$ \$ 38$ to 48 of Act No. 45/2013 Coll., On Crime Victims, the Ministry of Justice should not only support the activities of all subjects providing assistance to crime victims, but also provide the subjects with subsidies from the state resources. The condition for the special support from the state is an accreditation. The Ministry of Justice is also responsible for the evaluation of the conditions for the accreditation and decides as a responsible state administrative body about the accreditation itself. When and if an accreditation for a special body or subject is granted, it is regulated in the legal act On crime victims in the $\$ 40$ of Act No. 45/2013 Coll. ${ }^{62}$ The accredited subjects in order to obtain subsidies provide at least one of the two services, providing legal information or being active in some kind of restrictive programs. It is also the Ministry of Justice that maintains the register of providers of assistance to victims of crime. The register is on one hand important because of the listed subjects providing the assistance, but there are also on the other hand some problematic aspects in

$59 \$ 1$ paragraph 2 Act No. 85/1996 Coll., Act on Advocacy and also GřIVNA, Tomáš, ŠÁMAL, Pavel, VÁLKOVÁ, Helena. a kol., Zákon o obětech trestných činů. Komentár. 1. vydání. Praha : C. H. Beck, 2014, p. 45-48.

60 Compare with DURDÍK, Tomáš, ČÍRTKOVÁ, Ludmila, VITOUŠOVÁ, Petra, HÁKOVÁ, Daniela., Zákon o obětech trestných činů (č. 45/2013 Sb.). Komentár̆, Praha: Wolters Kluwer 2018, p. 48

61 See to that the legal act number 40/2009 Coll.

62 DURDíK, Tomáš, ČíRTKOVÁ, Ludmila, VITOUŠOVÁ, Petra, HÁKOVÁ, Daniela., Zákono obětech trestných činů (č. 45/2013 Sb.). Komentáŕ, Praha: Wolters Kluwer 2018, p. 259-263 
the relations of the contact information and possibilities how to reach the service providers. ${ }^{63}$

Differing from the activity of the Bar Association of the Czech Republic is the system introducing an advocate as a subject helping in the above-mentioned special system the victims of crime. The Ministry of Justice is at the request of the advocate and the corresponding state administrative body, entitled to register the advocate in the Register of assistance to victims of crime. An advocate has to mention inter alia, the scope of victims to whom the services will be provided. The advocate is also obliged to provide with the information of the number of the free legal aid hours he or she will provide to the victims of crime per month. After such a formal registration the lawyer is also obliged to fulfill this number of free legal hours, otherwise are they exposed to the possible penalty he or she will be removed from the register. The use of this sort of help, provided by a legal representative is described partially in the act No. 141/1961 Coll., The Criminal Procedure Code. ${ }^{64}$ For this legal aid can ask the particularly vulnerable victim without having to prove if the victim does or does not have sufficient financial resources for to cover the standard legal aid. ${ }^{65}$

\subsection{Right to protection against imminent danger}

The victims of crime are protected in situations where an imminent danger is shown, where the safety of victims is endangered. In those situations the police of the Czech Republic are obliged to act. The police are obliged to take measures to protect potential victims or current victims with the instruments of shortterm protection, where a person is protected by active police officers. Another instrument is the situation where the aggressor or highly suspected aggressor is expelled from the household. ${ }^{66}$

This described right to protection is codified in the $\$ 14$ of Act No. $45 / 2013$ Coll., On Crime Victims. The Czech legal system provides special protection of witnesses and other persons in connection with criminal proceedings thanks to the Act No. 137/2001 Coll., this law grants to witnesses special protection and is amending the law Act No. 99/1963 Coll. In situations using previously described instruments of special protection for the victims of crime, assistance of the court or public prosecutor is also necessary. They shall issue a precautionary measure in criminal proceedings. If it is a ban on access to a particular dwelling or a ban

63 For the specifications see JELÍNEK, Jiří a kolektiv: Zákon o obětech trestných činu․ Komentář s judikaturou. 2. vydání. Praha: Leges, 2014, p. 49.

64 See closer to the possible procedures for the victims of crime in the relations to the legal aid follow the $\$ 51$ of the Criminal procedure code.

65 JELÍNEK, Jiří a kolektiv: Zákon o obětech trestných činu․ Komentář s judikaturou. 2. vydání. Praha: Leges, 2014, pp. 50-52.

66 See also the $\$ 50$ of the Act No. 273/2008 Coll., On the Police of the Czech Republic 
on contact with exact persons, the criminal procedure code has to be used for those exact procedural steps taken by the court or public prosecutor. ${ }^{67}$

\subsection{Right to protection of privacy and to protection against secondary harm}

Privacy protection and protection against secondary harm are connected to the secondary victimization. Before describing the basic aspects of secondary discrimination we have to describe the legal regulation in the Czech legal system, the legal act On crime victims. As stated in $\$ \$ 15$ and 16 of the Act on Crime Victims Act No. 45/2013 Coll., the right to protection of privacy and against secondary harm both prohibit disclosure of information that would allow identification the victim, discovery of personal data of the victim, and both aim to achieve reducing the possibility of repeated or secondary victimization. ${ }^{68}$

At the victim's request, personal data such as the place of residence, employment, information about the victim's family, personal secrets shared only with law enforcement institutions, police and other institutions like probation and mediation service entitled to secure the rights of the victims of crime. Coming further to $\$ \$ 17$ to 22 of Act No. 45/2013 Coll., On Crime Victims, the protection against secondary harm and the secondary victimization is stipulated. Following the forementioned paragraphs, victims have the right to avoid a contact with a person identified by the victim as a perpetrator or suspect, or the prosecuted person. This right extends to persons close to the victim.

The victim is allowed to ask to be questioned by a person of the same sex, and may request to be heard by a person of the same sex in pre-trial proceedings, and it's also granted to be accompanied by a person of their choice, these are persons entrusted by the victims. The victims are so also in the position where they can request to write a statement, that is describing the impact of the crime on the victim's life. ${ }^{69}$

The victim has the right to request limitation of encounters with the perpetrator at any stage of the criminal proceedings; this request is primarily for victims who are particularly vulnerable. Competent authorities are obliged to comply with these requests unless the nature of the action is precluded..$^{70}$

The request of a particularly vulnerable victim must be granted by the competent authorities. Where an interpreter is needed, a particularly vulnerable victim may also apply for an interpreter of the same or opposite sex and the compe-

67 GŘIVNA, Tomáš, ŠÁMAL, Pavel, VÁLKOVÁ, Helena. a kol. Zákon o obětech trestných činů. Komentár. 1. Vydání. Praha : C. H. Beck, 2014, pp. 108-110.

68 Ibid, p. 130 and also DURDÍK, Tomáš, ČÍRTKOVÁ, Ludmila, VITOUŠOVÁ, Petra, HÁKOVÁ, Daniela. Zákon o obětech trestných činů (č. 45/2013 Sb.). Komentár., Praha: Wolters Kluwer 2018, pp. 153-158

$69 \$ \$ 17$ to 22 of Act No. $45 / 2013$ Coll., On Crime Victims

70 See to that JELÍNEK, Jiří a kolektiv: Zákon o obětech trestných činů. Komentář s judikaturou. 2. vydání. Praha: Leges, 2014, p. 102 
tent authorities are obliged to comply with that victims' request. A particularly vulnerable victim must be interviewed sensitively following the conditions of the circumstances that qualify them as a vulnerable victim. Interrogations should be conducted in such a way that they do not have to be repeated and should always be conducted by the same person working for the authority the same authority. This interrogation has to be carried out by a trained person. In this connection and above-described situations especially important is the requirement of the prevention of the secondary victimization, particularly in the case of interrogation of children and adult victims of crimes involving violence or sexual dignity crimes, where the victims are typically raped women. ${ }^{71}$

The legal regulation follows the harmonization tendency of the above mentioned Directive. A victim has the right to be accompanied to criminal proceedings and to explanations by a person of their choice who provides psychological support to the victim. Whoever accompanies a victim cannot intervene in the course of the criminal proceedings. In these situations the person of the confidant differs from the agent asked by the victim as described above. Confidant differs in the way that they represent the victim and ensure that the rights of the victim are respected. ${ }^{72}$

It was already mentioned that the victim has the right at any stage of criminal proceedings, to make a statement on the impact of the crime on their life, either in writing or orally. This reflects the right of the victims to be heard and provides information on the circumstances of the act leading to its clarification. This act also helps to protect the victim against secondary victimization and all the aspects where secondary victimization could cause harm to the victim. Describing secondary victimization and its basics could be useful for the purposes of this study.

Secondary victimization is a process or situation, when or where victims may be exposed to unpleasant behaviors, actions, and events during criminal proceedings which may create negative feelings and deepen their harm, the secondary victimization. Victimization can be divided into primary and secondary. In primary victimization, it is a direct injury by the perpetrator and manifests itself as an immediate consequence of the crime. The nature of the injury may be material in nature or most' often physical injury. Secondary victimization can be a negative reaction from the society which the victim is experiencing due to the primary victimization. ${ }^{73}$

71 JELÍNEK, Jiří a kolektiv: Zákon o obětech trestných činu․ Komentář s judikaturou. 2. vydání. Praha: Leges, 2014, p. 103

72 DURDÍK, Tomáš, Č́́RTKOVÁ, Ludmila, VITOUŠOVÁ, Petra, HÁKOVÁ, Daniela. Zákon o obětech trestných činů (č. 45/2013 Sb.). Komentáŕ, Praha: Wolters Kluwer 2018, p.178

73 CAMPBELL, Rebecca., RAJA, Sheela. Secondary Victimization of Rape Victims: Insights from Mental Health Professionals Who Treat Survivors of Violence, Violence and Victims, V. 14 (3), 1999 [online]. Available at https://pubmed.ncbi.nlm.nih.gov/10606433/ 
We can speak about secondary victimization when the victim suffers a further, unnecessary injury in addition to all of these procedures. Secondary victimization involves a number of different negative phenomena such as victim defamation, not respecting the victim's privacy, damaging the victim's reputation, downplaying the harm, and blaming the victim. ${ }^{74}$

Secondary victimization was defined in the legal context of the Czech Republic in the year 2013, under Act No. 45/2013 Coll., On Victims of Crime, which defined secondary harm - secondary victimization - and sets basic principles for the authorities involved in the relationships towards the victims. In relation to victims, all law enforcement authorities have to be more sensitized in the future. The phenomena of secondary victimization includes defamation of the victim, blaming or transferring guilt to the victim, failure to respect the victim's privacy, damaging the victim's reputation, and harm downplay. Secondary victimization also occurs with the police, the victims' experience with the police department or individual officers' behavior is not always positive. Possible inappropriate behavior by the police causes further psychological harm to victims of crime and is one reason why victims are unwilling to cooperate with the police. ${ }^{75}$

Secondary victimization by the society and the most trusted people of a victim. Secondary victimization occurs when the media is informing the public about crime because of the risks of secondary injuries to victims and the possibilities of protection against crimes. ${ }^{76}$ Secondary victimization by courts, prosecutors, and lawyers is also possible. It is not limited to the police because these professions also come into frequent contact with the victim and should try to avoid inappropriate behavior towards the victim. ${ }^{77}$

\subsection{Right of the victims of crime to compensation by the state}

The victims of crime can also use the right to compensation by the state. This compensation could be asked by the victim who has been injured or has suffered significant losses. The family of the victim who died, the victim of the crime against human dignity in the sexual area, and children who are the victim of

74 ORTH, Ulrich, Secondary Victimization of Crime Victims by Criminal Proceedings. Social Justice Research 15, 313-325 (2002). [online]. Available at https://doi. org/10.1023/A:1021210323461

75 Compared to the situation in United States following the article written by 5 . D E L TORO, Juan and the others, The criminogenic and psychological effects of police stops on adolescent black and Latino boys, Proceedings of the National Academy of Sciences, 2019, 116 (17) 8261-8268; available at https://www.pnas.org/content/116/17/8261

76 TANDON, Neeti. Secondary Victimization of Children by the Media: An Analysis of Perceptions of Victims and Journalists, International Journal of Criminal Justice Sciences, Vol 2, Issue 2, 2007 [online]. Available at http://citeseerx.ist.psu.edu/viewdoc/download?doi= 10.1.1.681.1268\&rep=rep1\&type $=$ pdf

77 PATTERSON, Debra. The Linkage Between Secondary Victimization by Law Enforcement and Rape Case Outcomes, Journal of Interpersonal Violence, Vol. 26(2), pp. 328-347, available at https://journals.sagepub.com/doi/pdf/10.1177/0886260510362889 
abuse are entitled to claim financial assistance. The Czech legal system is granting this protection thanks to the $\$ \$ 23$ to 36 of Act No. 45/2013 Coll., On Crime Victims, these paragraphs are dealing with the financial assistance provided by the state, the formal requirements when asking for such a support, and the claim for material damages or non-material damages which are claimed against the offender and or the State. ${ }^{78}$

The legal regulation for the financial aid or financial assistant and the issues of financial assistance are currently regulated in the Act on Crime Victims and such as, relevant for financial assistance. Describing the kinds of financial assistance and the purposes for this kind of legal regulation, the Czech system differs between primary and secondary purposes of financial assistance. The secondary purpose of financial assistance is to repair damage caused by a crime, to create a wider range of beneficiaries, increasing the amounts of monetary aid and the transfer of the victim's claim to compensation and non-material damage from the offender to the state. ${ }^{79}$

Financial assistance as compensation from the material point of view has to be understood as a provision of a financial amount used to overcome the social situation connected to the victims position. It consists of covering the costs associated with the provision of other necessary services and regimes of assistance as for example the psychological and other assistance are. Important for the form of the request is $₫ 30$ and $₫ 31$ of the act On the protection of victims of crimes. Following the sessions, the victim must apply for financial assistance within two years of becoming aware of the harm caused by the crime and, at the same time, within five years of committing the offense. ${ }^{80}$

After fulfilling all the formal conditions and within the time frame of the law, the Ministry of Justice shall issue a decision on the application within 3 months of the commencement of the proceedings. Up to 30 days are added to this period if, for example, it is necessary to summon someone or to draw up an expert opinion. ${ }^{81}$ Thanks to the not so old concept of the legal act On the victims of crime also the victims of crime against the human dignity in the sexual field, and child

78 DURDÍK, Tomáš, ČÍRTKOVÁ, Ludmila, VITOUŠOVÁ, Petra, HÁKOVÁ, Daniela. Zákon o obètech trestných činů (č. 45/2013 Sb.). Komentář, Praha: Wolters Kluwer 2018, p. 189 and also JELÍNEK, Jiří a kolektiv: Zákon o obětech trestných činů. Komentár̆ s judikaturou. 2. vydání. Praha: Leges, 2014, p. 122

79 JELÍNEK, Jiří a kolektiv: Zákon o obětech trestných činů. Komentár s judikaturou. 2. vydání. Praha: Leges, 2014, s. 128-140 and DURDÍK, Tomáš, ČÍRTKOVÁ, Ludmila, VITOUŠOVÁ, Petra, HÁKOVÁ, Daniela. Zákon o obètech trestných činů (č. 45/2013 Sb.). Komentář, Praha: Wolters Kluwer 2018, p. 189 and following

80 DURDÍK, Tomáš, ČíRTKOVÁ, Ludmila, VITOUŠOVÁ, Petra, HÁKOVÁ, Daniela. Zákon o obètech trestných činů (č. 45/2013 Sb.). Komentáŕ, Praha: Wolters Kluwer 2018, pp. 230235 and GŘIVNA, Tomáš, ŠÁMAL, Pavel, VÁLKOVÁ, Helena a kol. Zákon o obětech trestných činů. Komentár. 1. vydání. Praha : C. H. Beck, 2014, s. 200-202.

81 Ibid 202 
victims of mistreatment by an entrusted are provided with financial assistance to cover the costs associated with the provision of professional psychotherapy or other professional services aimed at remedying non-material damage, unless the financial assistance has been already provided. ${ }^{82}$

Since 2006, the Austrian criminal procedural act includes a legal entitlement to psycho-social and legal assistance in proceedings ${ }^{83}$ for victims of violence stemming from an intentional crime, dangerous threats, as well as victims whose sexual integrity has been violated. Furthermore, persons whose personal dependency might have been used to commit an intentional crime are defined as victims having the right to psycho-social and legal assistance in proceedings. Personal dependency can for instance be important in cases of human trafficking where another person took advantage of their authority or an emergency situation. ${ }^{84}$

Psycho-social and legal assistance is to be provided throughout the proceedings free of charge. Assistance includes for instance accompanying the person to the police when making a report, informing about and preparing for criminal proceedings, accompanying victims to questionings at court, and to the trial. Legal assistance means that a lawyer represents the victim in criminal proceedings. In civil proceedings, psycho-social assistance is granted when the civil proceedings are related to the criminal proceedings. ${ }^{85}$

In case of domestic violence, stalking, or trafficking of human beings, victims are automatically referred to support organizations and personal data is transferred from police to the support organization. ${ }^{86}$ For example, when the police impose a barring or restraining order for the perpetrator in case of domestic violence, the intervening police officer has to inform the victim support organization (intervention center) about the order without any delay and after that, the support organization contacts the victim proactively. ${ }^{87}$ By the latest amendment of the Federal Protection against Domestic Violence Act in 2019, the possibility of

$82 \$ 28$ paragraph 1, d of Act No. 45/2013 Coll., on Crime Victims

83 Austrian Code on Criminal Procedure, FLG 403/1977 as amended by FLG I 24/2020, section 66 (2).

84 See CEDAW, Consideration of reports submitted by States parties under article 18 of the Convention - 9th periodic report Austria, 4 April 2017, paras 108-111.

85 See Domestic Abuse Intervention Centre Vienna/Association of Austrian Autonomous Women's Shelters, Victims' Rights to Support and Protection from Violence (6th edition 2019), 11.

86 This is based on section 25 of the Austrian Security Police Act. See on this Nachbauer, Die richtige Linie - Gesetzliche Grundlagen und praktische Umsetzung der Unterstützungsleistung für Opfer in Österreich, in SAUTNER, Lyane, JESIONEK, Udo, Opferrechte in europäischer, rechtsvergleichender und österreichischer Perspektive, VOR 8 (StudienVerlag 2017), p. 217.

87 The relevant provisions in for instance the Security Police Act or the Code on Criminal Procedure are collected in the Federal Protection against Domestic Violence Act 1997, as amended by its latest amendment in 2019 . 
conducting 'case conferences' in selected high-risk cases has been implemented based on experiences made during a project on multi-agency risk assessment conferences. Law enforcement authorities can coordinate the next steps and further solutions in a case with other authorities or institutions including victim support centers, clinicians, social workers, or school authorities. Concerning cases that do not fall under the aforementioned categories, the transfer of personal data is possible based on a signed consent form. Since 2016, police officers are obliged to inform victims verbally about the possibility to have the victim support organization 'Weißer Ring' informed based on the consent form. Before that, a leaflet was handed out to public. $^{88}$

The Ministry of Justice assigns organisations that provide psycho-social and legal assistance. The non-profit organization 'Weißer Ring', established in 1978, supports all victims of crime in Austria and is partially funded by the Ministry of Justice. 'Weißer Ring' runs the victims hotline 0800112112 which is funded by the Ministry of Justice. Furthermore, there are specialized victim support organisations such as intervention centers for domestic abuse, or trafficking in women, which are partly funded by the Ministry of Interior and the Ministry of Justice.

Directive 2012/29/EU requires EU Member States to ensure the minimum standards in the field of victim protection. This harmonization trend is reflected also in Germany. The need for implementation for Germany was taken into account thanks to the Act Strengthening of Victims' Rights in Criminal Proceedings. Compared to the other countries, Germany has yet to follow implementation in a few areas such as procedural and information rights. ${ }^{89}$

Weisser Ring in Germany was founded in Mainz in 1976 as a registered "Non-profit Association to Support Victims of Crime and Prevent Criminal Offences". It is Germany's largest victim protection organisation and offers victims of crime quick and non-bureaucratic support. The association has a network of approximately 3,200 voluntary victim supporters in 420 local branches all over Germany. Weisser Ring has around 50,000 members and is divided into 18 regional associations. The organisation is an expert and recognised partner for politics, the judiciary, administration, science, and media on all questions

88 See NACHBAUER, Diana. Die richtige Linie. Gesetzliche Grundlagen und praktische Umsetzung der Unterstützungsleistungen für Opfer in Österreich. In: SAUTNER, Lyane, JESIONEK, Udo, Opferrechte in europäischer, rechtsvergleichender und österreichischer Perspektive, VOR 8 (StudienVerlag 2017), p.218.

89 The 3rd Act to Reform the Protection of Victims' Rights was adopted in December 2015 and entered into force on 31 December 2015 (with the exception of the provision concerning psycho-social support during the proceedings (Art. 1 no. 12 and Art. 4), which entered into force on 1 January 2017). The act implements Directive 2012/29/EU of the European Parliament and of the Council establishing minimum standards on the rights, support and protection of victims of crime. On 1 September 2004, the 1st Act to Reform the Protection of Victims' Rights entered into force. The aim of the recast regulation focused on strengthening the rights of victims during criminal proceedings. 
involving victim support and protection of victims. Weisser Ring finances its activities from member fees, donations, fines imposed in court proceedings, and from testamentary bequests. ${ }^{90}$

Analyzing the German system from the point of the victim rights view, a wide range of victim-protection measures has been implemented before the necessary implementation of the Directive 2012/29/EU of the European Parliament and of the Council establishing minimum standards on the rights, support, and protection of victims of crime procedure in Germany and not only in the Code of Penal Procedure. ${ }^{91}$

Because of the protection of the needs and rights of an injured person, the beginning of the Code of Penal Procedure - StPO has been changed and the new regulation anchored in $\$ 48$ of the StPO. This new law is connected to the minimum standards for the rights of victims of crime. In the future all hearings and interviews must be carried out with due thought given to the specific requirements for the protection of the victims. Important are the aspects of the possibility of hearing witnesses in the absence of the defendants according the $\$ 168 \mathrm{e}$ of the Penal Procedure Code, and if required, using audio-visual hearings according the $\$ 247$ a of the Penal Procedure Code, or to hold closed hearings during the main proceedings according the $\$ 171 \mathrm{~b}$ para. 1 of the Judicial Systems Act, as well as restricting questions asked concerning the witnesses' private lives according to $\$ 48$ of the Penal Procedure Code. ${ }^{92}$

The victims' information rights and duties regarding their powers during and outside the criminal proceedings are also guaranteed by law. The scope of the victims' rights to information about the proceedings has been somewhat broadened according to $\$ 406 \mathrm{~d}$ of the Penal Procedure Code. Various duties concerning the provision of access to information have been restructured in $\$ \$ 406 \mathrm{i}$ to $406 \mathrm{k}$ of the Penal Procedure Code. Finally, the right of victims to access interpretation and translation services is set forth in the federal law. At the same time, this means that criminal prosecution authorities have heightened obligations to provide information. In the future, the victims must receive a written confirmation of the charges filed if they demand it.

New in the regime of the protection of victims of crimes is also the Act Psycho-Social Support during Court Cases. This law provides for a right to psychosocial support during the proceedings for children and young victims of sexual and violent offences, for adults, the decision is struck at the discretion of the court following the $\$ 406 \mathrm{~g}$ of the Penal Procedure Code (PPC). The law defines

90 More information to the german Weiser Ring situation at http://www.infovictims.de/de en/weisser-ring-ev

91 Code of Criminal Procedure as published on 7 April 1987 (Federal Law Gazette I, p. 1074, 1319), as last amended by Article 3 of the Act of 11 July 2019 (Federal Law Gazette I, p. 1066)

92 Ibid $₫ 48$ 
the principles underlying the psycho-social support provided during court cases and sets forth the requirements for qualifications and payment of the psychosocial counsels during the proceedings. The exact structure of these matters is the responsibility of the federal states. ${ }^{93}$

It is of central importance to determine whether or not an injured person is particularly vulnerable. Following this principle, the new legal regulation contains the protection of the particularly vulnerable victim - in addition to children and adolescents, special needs for protection can also be considered for people with disabilities or mental impairments, for elderly, sick and frail people, for those affected by sexual offences, violence and hate crime, in particular those motivated by prejudice, and for those affected by trafficking human beings. The special need for protection with regard to the question of the classification of psychosocial, legal assistance is determined solely by the competent court.

The necessary information on the rights and the status of the proceedings was implemented by the provision of $\$ 406 \mathrm{~d}$ PPC, according to which the injured party must be informed of the date and place of the main hearing, and of the accusations made against the accused. The victim must now also be informed if the accused or convicted person has escaped from custody. These communication obligations are normally the duties of the Public Prosecutor's Office. However, if the accused is expected to be remanded in custody, the information will be provided by the police in accordance with $\$ 406 \mathrm{~d}$ PPC. The new codification is setting the mandatory obligation to inform the injured person of their rights. Injured persons shall be informed as early as possible, regularly in writing, and as far as possible, in a language intelligible to them, and in particular to point out the following aspects. Injured persons may bring an offence to the attention of the court or file a criminal complaint. In this context, they must be informed of the resulting modalities, competences, formalities and deadlines. ${ }^{94}$

Victims shall be informed at an early stage of how and under what conditions they are entitled to legal assistance, interpreting, and translation. Victims should be also informed about how and under what conditions expenses incurred by them as a result of their participation in criminal proceedings and compensation under the Crime Victims' Compensation Act. ${ }^{95}$ Following this law, the claimants in question must have been the objects of an act of violence and they must suffer from after-effects as a result of said act. Both, the direct victims or their surviving relatives are entitled to compensation under this legislation. The Crime Victims' Compensation Act defines an act of violence as a deliberate unlawful violent

93 See also the official information [online]. Available at https://mieterschutz.bund.de/ SharedDocs/Gesetzgebungsverfahren/DE/Staerkung_Opferrechte_Strafverfahren.htmlo

94 See to that $\$ \$ 406$ d-406h, 406i p. 1 no. $1-5$ PPC

95 Crime victims Compensation Act as promulgated on 7 January 1985 (Federal Law Gazette I S. 1), last amended by Article 2a of the Act of 15 April 2020 (Federal Law Gazette I p. 811) - JVEG. 
attack against a person, e.g. intentional bodily harm, rape, sexual assault, sexual abuse, etc. Every type of health-related problem that results from said acts of violence entitles the victim to demand compensation. Health-related problems include physical and/or psychological problems, and they may be temporary or permanent. These health issues must be directly caused by the act of violence in question. The rights to entitlements under the Crime Victims' Compensation Act are decided upon by the Support Offices "Versorgungsamt" upon request. However, in every federal state, these offices bear different names. The administrative process is closed by means of a notification and it can be appealed. If the Support Office does not see the need for remedy, the next higher authority shall decide upon the case. In addition, injured persons must be made aware of the possibility of compensation for perpetrators and victims. In principle, the Public Prosecutor's Office is responsible for the instructions mentioned above. However, the injured person should be informed about his rights as soon as possible. As soon as possible means, it is to be handed over to the injured person at the time of receipt of the criminal charges and at the latest at the time of the first hearing. ${ }^{96}$

Victims shall be informed also about the type of assistance they may receive outside the criminal proceedings, from whom they may receive the assistance and on access possibilities. The victim must be informed that compensation can be claimed not only in criminal proceedings by means of the adhesion procedure, but also the possibility of asserting claims by civil law, with the possibility of applying for legal aid provided for therein. ${ }^{97}$

Pursuant to Section 406j No. 5 PPC, the police are to point out possible assistance and to inform the injured person which facilities they can contact. In individual cases, it may be appropriate to mediate the victim with their consent directly to a victim support institution. ${ }^{98}$

A special form of the new system of support is psychosocial support. Victims of crime receive special intensive care before, during, and after the trial. This care includes qualified support, information, and assistance in criminal proceedings including police interrogations. For some of the victims this offer is prepared for free, for victims of serious crimes with a special need for protection, such as children and adolescents, people with mental or age-related impairment. In accordance with Section 406i of the PPC, the police and the judiciary authorities must inform victims of the possibility of using psychosocial legal assistance and should also document this. ${ }^{99}$

96 See to that the Section 155a of the PPC

97 In Paragraph 406j No. 4 of the PPC, a requirement to indicate the possibility of compensation under the JVEG was inserted.

98 The online database for those affected by crime (www.odabs.org) can help to find care and counselling centers near the victim's place of residence. The institutions specialize in supporting victims of sexual and violent crimes.

99 Compare this with the information [online]. Available at https://www.bmjv.de/DE/Themen/ OpferschutzUndGewaltpraevention/Prozessbegleitung/Merkblatt_Prozessbegleitung_Englisch.pdf?_blob=publicationFile\&v $=1$

Published by Palacký University Olomouc, Czech Republic, 2020.

ISSN (print): 1213-8770; ISSN (online): 2464-6601 


\section{Conclusion}

From these illustrative cases of the EU Member States, it can be the need for harmonization and may be in the future also unification of the different systems of assistance to victims of crime concluded which are different can be observed. There are common features but also many differences between countries. The main difference is the existence or absence of a separate law regulating the issue of crime victims. The majority of EU Member States have transposed the Directive through several existing and new legal provisions. ${ }^{100}$

As shown in the assessment of the European Commission, the requirement to conduct an individual assessment of a person's protection needs are mentioned in Article 22 of Directive 2012/29/EU, are not implemented or is only partially implemented in several EU Member States. ${ }^{101}$ The way individual assessments are conducted in the EU Member States varies greatly. ${ }^{102}$

The transposition of Directive 2012/29/EU is assessed by the European Commission as not satisfactory and there are numerous concerns in relation to the practical implementation of the Directive. ${ }^{103}$ For example, Article 3 of Directive $2012 / 29 / \mathrm{EU}$ on the right to understand and to be understood is transposed by some States as an explicit right, but it is not specified how this should be implemented in practice. ${ }^{104}$ Research shows several obstacles for the Directive's implementation in practice such as unwillingness, a non-victim oriented issue. There is more harmonization and maybe also unification needed.

That's why it is also important, that on the $24^{\text {th }}$ June, 2020 the European Commission presented for the first time an EU strategy on victims' rights. It aims to ensure that all victims of crime can fully exercise their rights, regardless of where the offence has been committed in the EU.

The EU has already initiated many procedures to harmonize the legal aspect of protection of the victim rights and to ensure victim's rights in the Member States. However, victims of crime still cannot fully rely on the fact that they can exercise their rights under EU law. The starting point must be better applica-

100 SCHERRER, Amandine et al., The Victims' Rights Directive 2012/29/EU - European Implementation Assessment (European Parliament 2017), [online]. Available at https://www.europarl.europa.eu/RegData/etudes/STUD/2017/611022/EPRS_STU(2017)611022_EN.pdf

101 European Commission, Report from the Commission to the European Parliament and the Council on the implementation of Directive 2012/29/EU, COM(2020)188 final, 11 May 2020, 8.

102 SCHERRER, Amandine et al., The Victims' Rights Directive 2012/29/EU - European Implementation Assessment (European Parliament 2017), p.15.

103 European Commission, Report from the Commission to the European Parliament and the Council on the implementation of Directive 2012/29/EU, COM(2020)188 final, 11 May 2020, 9.

104 SCHERRER, Amandine et al., The Victims' Rights Directive 2012/29/EU - European Implementation Assessment (European Parliament 2017), p. 51. 
tion of EU rules in practice. The new strategy presented by the European Commission provides a package of measures with five most important aspects. It is for the future necessary to communicate effectively with victims and to create a safe environment for victims to report criminal offenses. Even in this study it was shown that even if the victims are better protected in the relationship to the rights, there is further need to improve the protection and support of the most vulnerable victims. Not only at the European level and in the relationship to facilitation of the better way to the victims' access to compensation and the legal instruments. Future collaboration of the Member States and the supreme buddies of the European Union shall enhance the cooperation and coordination between actors in the area of victims' rights and strengthen the international dimension of victims' rights. Let's watch over and analyze the future situation with the hope that this study can help to organize and prepare all the activities and procedures mentioned above.

\section{List of references}

CAMPBELL, Rebecca., RAJA, Sheela. Secondary Victimization of Rape Victims: Insights from Mental Health Professionals Who Treat Survivors of Violence, Violence and Victims, V. 14 (3), 1999 [online]. Available at https://pubmed.ncbi.nlm.nih.gov/10606433/.

CEDAW Report, Consideration of reports submitted by States parties under article 18 of the Convention - 9th periodic report Austria, 4 April 2017, p. 108-111.

Code of Criminal Procedure as published on 7 April 1987 (Federal Law Gazette I, p. 1074, 1319), as last amended by Article 3 of the Act of 11 July 2019 (Federal Law Gazette I, p. 1066).

DE CASADEVANTE ROMANI, Fernández, International Law of Victims, Max Planck Yearbook, Vol. 14, 2010, pp. 219-272, 227.

DEL TORO, Juan. and the others, The criminogenic and psychological effects of police stops on adolescent black and Latino boys, Proceedings of the National Academy of Sciences, 2019, 116 (17) 8261-8268; [online]. Available at https://www.pnas.org/content/116/17/8261.

Domestic Abuse Intervention Centre Vienna/Association of Austrian Autonomous Women's Shelters, Victims' Rights to Support and Protection from Violence (6th edition 2019), p. 11. [online]. Available at https://www.interventionsstelle-wien.at/.

DURDÍK, Tomáš, ČíRTKOVÁ, Ludmila, VITOUŠOVÁ, Petra, HÁKOVÁ, Daniela. Zákon o obětech trestných činů (č. 45/2013 Sb.). Komentář, Praha: Wolters Kluwer 2018, P. 456.

European Commission, Report from the Commission to the European Parliament and the Council on the implementation of Directive 2012/29/EU, COM(2020)188 final, 11 May 2020.

Final report on the implementation of Directive 2012/29/EU establishing minimum standards on the rights, support and protection of victims of crime, [online]. Available at https://www.europarl.europa.eu/doceo/document/A-8-2018-0168_EN.html (2016/2328(INI)).

GŘIVNA, Tomáš, ŠÁMAL, Pavel, VÁLKOVÁ, Helena a kol. Zákon o obětech trestných činů. Komentář. 1. vydání. Praha : C. H. Beck, 2014, P. 544. 
Handbook on Justice for victims, on the use and application of the declaration of basic principle of justice for victims of crime and abuse of power, UNODC, Center for international crime prevention, New York, 1999 [online]. Available at http https://www. unodc.org/pdf/criminal_justice/UNODC_Handbook_on_Justice_for_victims.pdf.

JELÍNEK, Jiří. a kolektiv: Zákon o obětech trestných činů. Komentář s judikaturou. 2. vydání. Praha: Leges, 2014, P. 320

JELÍNEK, Jiří., GŘIVNA, Tomáš.: Poškozený a obět trestného činu z trestněprávního a kriminologického pohledu. Praha Leges, 2012, 256 p.

LETSCHERT, Rianne, VAN DIJK, Jan, The New Faces of Victimhood: Globalization, Transnational Crimes and Victim Rights, Springer Science \& Business Media, 2011, $343 \mathrm{p}$.

NACHBAUER, Diana. Die richtige Linie. Gesetzliche Grundlagen und praktische Umsetzung der Unterstützungsleistungen für Opfer in Österreich. In: Sautner, L., Jesionek, U.: Opferrechte in europäischer, rechtsvergleichender und österreichischer Perspektive. Innsbruck: StudienVerlag 2017, pp. 215-236.

ORTH, Ulrich, Secondary Victimization of Crime Victims by Criminal Proceedings. Social Justice Research 15, 313-325 (2002). [online]. Available at https://doi. org/10.1023/A:1021210323461.

PATTERSON, Debra. The Linkage Between Secondary Victimization by Law Enforcement and Rape Case Outcomes, Journal of Interpersonal Violence, Vol. 26(2), pp. 328-347, [online]. Available at https://journals.sagepub.com/doi/ pdf/10.1177/0886260510362889.

SCHERRER, Amandine et al., The Victims' Rights Directive 2012/29/EU - European Implementation Assessment (European Parliament 2017), [online]. Available at https://www.europarl.europa.eu/RegData/etudes/STUD/2017/611022/EPRS_ STU(2017)611022_EN.pdf.

SHAPLAND, Joanna. The Guide for Practitioners Regarding the Implementation of the Declaration of Basic Principles of Justice for Victims of Crime and Abuse of Power: Report : Item 7 of the Provisional Agenda [for The] Eighth United Nations Congress on the Prevention of Crime and the Treatment of Offenders, Havana, UN, 1990.

SAUTNER, Lyane, JESIONEK, Udo, Opferrechte in europäischer, rechtsvergleichender und österreichischer Perspektive, VOL 8 (StudienVerlag 2017, p. 336.

TANDON, Neeti. Secondary Victimization of Children by the Media: An Analysis of Perceptions of Victims and Journalists, International Journal of Criminal Justice Sciences, Vol 2, Issue 2, 2007 [online]. Available at http://citeseerx.ist.psu.edu/viewdoc/downlo ad?doi=10.1.1.681.1268\&rep=rep1\&type=pdf.

WALLER, Irvin, Rights for Victims of Crime: Rebalancing Justice, Rowman \& Littlefield Publishers, 2010, ISBN 9781442207073, 232 p. , the texture [online]. Available at https://www.lehmanns.de/shop/recht-steuern/26304040-9781442207073-rights-forvictims-of-crime.

Act No. 273/2008 Coll., On the Police of the Czech Republic.

Act No. 45/2013 Coll., On Crime Victims of the Czech Republic.

Act No. 45/2013 Coll., on Victims of Crime of the Czech Republic.

Act No. 45/2013 Coll., On Victims of Crime of the Czech Republic.

Act No. 85/1996 Coll., Act on Advocacy of the Czech Republic.

Act number 40/2009 Coll. Criminal Code of the Czech Republic.

Austrian Code on Criminal Procedure, FLG 403/1977 as amended by FLG I 24/2020. 
ICLR, 2020, Vol. 20, No. 2.

European Convention on the Compensation of Victims of Violent Crimes, Convention number 116, on 24 November 1983.

Crime victims Compensation Act as promulgated on 7 January 1985 (Federal Law Gazette I S. 1), last amended by Article 2a of the Act of 15 April 2020 (Federal Law Gazette I p. 811) - JVE.

Directive 2011/36/EU available at http://eurlex.europa.eu/LexUriServ/LexUriServ.do?uri $=\mathrm{OJ}: \mathrm{L}: 2011: 101: 0001: 0011: \mathrm{EN}: \mathrm{PDF}$

Directive 2011/92/EU available at http://eurlex.europa.eu/LexUriServ/LexUriServ.do?uri $=\mathrm{OJ}: \mathrm{L}: 2011: 335: 0001: 0014: \mathrm{EN}: \mathrm{PDF}$

Directive 2011/99/EU on the European Protection Order available at https://eur-lex. europa.eu/legal-content/EN/TXT/?uri=celex\%3A32011L0099

UN Convention on Justice and Support for Victims of Crime and Abuse of Power.

Regulation 606/2013/EU on the mutual recognition of protection measures in civil matters.

Project RIVI site - https://bim.lbg.ac.at/en/rivi.

BMJ, [online]. Available: https://mieterschutz.bund.de/SharedDocs/Gesetzgebungsverfahren/DE/Staerkung_Opferrechte_Strafverfahren.html

BMJ, [online]. Available: https://www.bmjv.de/DE/Themen/OpferschutzUndGewaltpraevention/Prozessbegleitung/Merkblatt_Prozessbegleitung_Englisch.pdf? blob=publicationFile\&v $=1$

Council of Europe: [online]. Available : https://www.coe.int/en/web/conventions/fulllist/-/conventions/treaty/116, Information to the german Weiser Ring, [online]. Available : http://www.infovictims.de/de_en/weisser-ring-ev

The report of the European Institute for Gender Equality, [online]. Available : http://eige. europa.eu/sites/default/files/Violence-against-Women-Victim-Support-Report.pdf

The online database for those affected by crime (www.odabs.org) 